\title{
Analysing stereotypes and prejudices about immigrant students in European secondary education.
}

\author{
Olga Moreno-Fernández* \\ Faculty of Education Sciences, University of Seville, Seville, Spain \\ ORCID: 0000-0003-4349-8657 \\ Elena Guichot-Muñoz \\ Faculty of Education Sciences, University of Seville, Seville, Spain \\ ORCID: 0000-0001-6017-8837 \\ Giulia De Sarlo \\ Faculty of Education Sciences, University of Seville, Seville, Spain \\ ORCID: 0000-0002-7204-258X

\section{Mario León-Sánchez} \\ Faculty of Education Sciences, University of Seville, Seville, Spain \\ ORCID: 0000-0002-2649-944X
}

Article history

Received:

04.05.2020

Received in revised form: 08.07.2020

Accepted: 16.07.2020

Key words: Stereotypes; Immigration; Secondary Education, Inclusion.
This study is part of the QuamMELOT Erasmus+ Project, whose objective is to improve the educational and social inclusion of immigrant minors in general and unaccompanied foreign minors (UFM), through an online course for secondary school teachers with this type of students. This paper aims to analyse the stereotypes and prejudices about immigrant students in secondary education in three European countries: Spain, Greece and Italy. For this purpose, a content analysis of the products generated during the course by teachers has been carried out with a cross-sectional and structured methodology, focused on a descriptiveinterpretative analysis according to the qualitative paradigm. The results show an increase in xenophobic statements as perceived by teachers. They believe that this is due to the impact of the global phenomenon of migration on the media, which affects everyday conversations, and a climate of fear exacerbated by populist voices in the political sphere. Moreover, through the analysis of the exercises proposed in the real class through the online course, it is interesting to observe the diversity of the students' reactions to a literary

\footnotetext{
*Correspondency: omoreno@ us.es, telephone: +34 955420665
} 
exercise that proposes a controversy about the "colonial difference" that still persists today. There is likewise awareness among teachers of a lack of methodological strategies to break down the prejudices and stereotypes that exist in their classrooms. It also highlights the need to raise awareness in the classroom about this danger, which is at the root of the principles of acceptance and multiculturalism on which Europe is founded.

\section{Introduction}

This work is part of the QuamMELOT Erasmus+ Project. The main objective of this project is to improve the educational and social inclusion of migrant minors in general and of Unaccompanied Foreign Minors (UFM) in particular, since this inclusion is affected by social, economic, political and cultural issues, among others, of the countries of arrival.

Over the last few decades and more than ever before, Spain has faced the challenge of both legal and illegal immigration. According to the Ministry of Home Affairs, in 2019 the arrival of immigrants to Spanish territory, both by sea and by land, has recorded a total of 29,775 units, $49.8 \%$ less than in the previous year, although this is still a considerable figure.

These migratory waves, especially in their illegal aspect through the so-called Mediterranean route and the route from West Africa to the Canary Islands, have also led to the arrival of young immigrants to the EU in several cases who are minors and unaccompanied (UFM), this being a growing social phenomenon, especially in Mediterranean countries. As far as minors are concerned, more than 12,500 foreign children have been identified in Spain as travelling alone, according to the official (but not definitive) register of the Ministry of Home Affairs.

All foreign minors, even without a residence permit, have the right to enrol at school (United Nations Convention on the Rights of the Child, 1989; Strasbourg Convention, 1983). Member States have ratified FM's enrolment in public schools with specific rules in order to complete their education and training. In the case of Spain, 218,180 foreign students were enrolled in Compulsory Secondary Education (12-18 years old) for 2018/2019 school year (Ministry of Education, 2020).

The media's treatment of the arrival of foreign immigrants in general, and of foreign minors in particular, together with the social and economic problems which European countries have been facing during the last decade, have highlighted situations where stereotypes and prejudices about these people have sometimes complicated their integration and the coexistence of different social sectors.

There is a negative image towards immigration and cultural diversity that does not help intercultural relations: and this problem involves school too, since, as León, Felipe and Gómez (2010, p. 359) point out, "the interaction in the classroom between native students and immigrants is not exempt from difficulties and inconveniences and will be influenced by the attitudes that the former maintain towards the latter. If negative, these attitudes can lead directly to prejudice and discrimination" (translations are all by the 
authors).

This new cultural perspective implies new challenges for teachers, and a deep reflection on that is needed: in particular, it is urgent to carry out a comprehensive and specific study on the effects that multiculturalism generates in the educational system and on the prejudices and stereotypes that are generated in the classroom towards immigrant students in the European context (Fruja \& Roxas, 2016; Strandberg \& Lindberg, 2012; Glick \& Hohmann-Marriott, 2007; Holm y Londen, 2010; Navas, Holgado \& Sánchez, 2009; Allemann-Ghionda, 2009: Woolfolk, 2006; Porter \& MacLeod, 1996). For all that, it is imperative to work in classrooms on these stereotypes and prejudices, promoting multicultural education, focusing on issues that highlight the conditions of immigrants through their life stories, letters, songs and other cultural elements from their countries of origin, through discussions about personal reasons that may force someone to leave their country, about cases of injustice and the identification of infringements of rights and freedoms, and about values such as cooperation and empathy with migrants, since it is only by learning about equality in diversity that attitudes such as racism and xenophobia, and hence stereotypes and prejudices present in our society, can be eradicated (Parejo-Llano, Ruiz-Requies \& González-Pedraza, 2020).

From this point of view, educational science has been proposing an epistemological and pedagogical change that marks a new direction. In order to subvert the artificial homogenisation of culture in the classroom, a decolonial critical pedagogy can be implemented in order to rethink and reconstruct societies from the questioning of the bases of modernity, challenging the Eurocentric, Western and neo-liberal paradigm (Wane \& Todd, 2018; Walsh, 2014; Castro-Gómez \& Grosfoguel, 2007). The activities presented and analysed here are based on this new approach, which will be further developed in the discussions. Likewise, the proposal also expresses the objective of implementing strategies that transform the teacher's attitude: dynamics that favour cooperative learning (Morales, 2006), reflective writing practices (Krulatz \& Iversen, 2020), intercultural communication (Samovar Porter \& Roy, 2014), and creativity (Oltra, 2015; Hajisoteriou \& Angelides, 2017) as a way of enriching the experience of diversity in the classroom.

\section{Method}

\section{Research Design}

The aim of this research is to analyse the stereotypes and prejudices about immigrants through the classwork prepared by students and teachers of Compulsory Secondary Education participating in the QuamMELOT project. These activities have been carried out in class groups that included immigrant students.

A content analysis has been carried out (López-Noguero, 2002), focusing mainly on the manifest contents (Piñuel, 2002). A cross-sectional and structured methodology has been used to develop a descriptive-interpretative analysis within the qualitative paradigm.

\section{Participants and description of the teacher online course}


The participants were 39 Compulsory Secondary school teachers who took part in the QuamMELOT online course. They made a previous theoretical and practical reflection, a didactic application in the classroom and a self-evaluation of the final learning. A total of 117 documents have been analysed.

Here are the three tasks that have been carried out with their corresponding objectives, timing, resources and generated products.

\section{Activity 1: Recognizing and identifying our prejudices towards others (objective)}

\section{Timing: 25 hours}

Resources for teachers: Van Dijk, T.A. (2001). Discourse and Racism. In D. Goldberg \& J. Solomos (Eds.), The Blackwell Companion to Racial and Ethnic Studies. Oxford. Eclipse".

Resources to work in the classroom: Micro-story by Augusto Monterroso "The

\section{Activity focused on teachers: theoretical and practical reflection}

Timing: 10 hours ( $3 \mathrm{~h}$ reading $+7 \mathrm{~h}$ reflection and task)

The text written by Van Dijk was a milestone in the world of sociology for showing the perpetuation of racism among the various dominant hegemonies: political, academic and media. This text, therefore, speaks about racism in different areas: in conversations, in news reports, in textbooks and in political speeches.

\section{Task}

Focus on the concept of prejudice established by Van Dijk (2001, p. 126):

What processes are involved in stereotyping? Hall (1997, p. 268) writes that stereotypes take over the few "simple, vivid, memorable, easily grasped, and widely recognized characteristics of a person, reduce everything about that person to those features, exaggerate and simplify them, and fix them without change or development into eternity".

Teachers are asked to write a reflection showing examples of this racism that have been experienced in the following contexts: press, political parties, textbooks and colloquial street conversations. It should also consider how a class session could be developed to explain to students how to detect racism, even when it's not explicit.

\section{Product 1}

The following table will be provided in full (table 1):

Table 1. Examples of racism and explanation and detection

\begin{tabular}{l}
\hline Examples of racism \\
\hline Political parties \\
Colloquial conversations on the street \\
Press \\
Textbooks
\end{tabular}

The aim of this task is to show students how to detect these situations and to banish racist stereotypes and prejudices that are created in society, as well as to encourage 
them to learn more about the different cultures that are already present in the classroom.

\section{Product 2 - Focused on students: reading-reflection-action (Classroom practice)}

Timing: 15 hours (Preparation 11h- Classroom sessions 4h). At least four classes of 45 minutes will be dedicated to this activity (table 2).

Table 2. Classroom sessions

15 minutes: Reading of the beginning of Augusto Monterroso's The 1st class Eclipse micro-story. 30 minutes: Writing in groups of the finals. 30 minutes: Exhibition on the board (by spokespersons) of the

2nd class alternative endings. 15 minutes: Reading of Monterroso's story ending.

3rd class 45 minutes: reflection/discussion.

4th class 45 minutes: individual reflection on what was discussed in class.

To achieve the objective of this activity, it is also necessary to work with students to recognize and identify our prejudices towards others, starting with the reading of a micro-story by the Guatemalan writer Augusto Monterroso: "The Eclipse". First published in 1959, its brevity, irony and ethical implications make it the perfect piece of literature to work with students of this school age. The story is simple: Conquest era, Yucatan jungle; a friar is captured by the Indians who decide to sacrifice him. To save his life, the friar clings to his knowledge:

Then an idea flourished in him that he considered worthy of his talent and universal culture and of his arduous knowledge of Aristotle. He recalled that a total eclipse of the sun was expected for that day. And he disposed, in his heart, to use that knowledge to deceive his oppressors and save his life.

-If you kill me," he said, "I can make the sun darken in its height.

The Indians stared at him, and Bartholomew was surprised by the incredulity in their eyes. He saw that there was a little advice, and waited confidently, not without some disdain.

The last paragraph of the story is not shown to students, and they are invited to provide endings for the story. Each student group will discuss different options, collectively write their ending and propose it to the class. Different options will be written down on the blackboard; only after that, the true end of the story will be read aloud:

Two hours later, the heart of Fray Bartolomé Arrazola was dripping its vehement blood on the sacrificial stone (shining in the opaque light of an eclipsed sun), while one of the Indians was reciting without any voice inflection, without hurry, one by one, the infinite dates when solar and lunar eclipses would occur, which the astronomers of the Mayan community had foreseen and written down in their codices without the valuable help of Aristotle.

\section{Reflection}

A series of questions are raised in order to awaken students' critical thinking. We propose some that can be extended according to the teachers' own perception/choice and the contents that are being studied. 
- What happened in the story?

- What has been the reaction of the Indians? Why?

- Do you know why they are called "Indians"? From what perspective?

- What is the difference between civilization and barbarism?

- What do you identify him with?

- What were the endings written by the students?

- How do they differ from the ending written by Augusto Monterroso?

Based on these reflections, we will propose a debate on the prejudices related to American cultures, which will highlight the stereotypes from which we organize the information that comes to us from outside.

\section{Product 3 - Focused on teachers}

An essay of at least 500 words will be written on the experience developed in class.

\section{Activity 2: Experiencing my change [Self-evaluation]}

Timing: 5 hours

For the teachers: theoretical and practical reflection

Task

Read the following fragments:

"The entry of immigrant students into Spanish schools in recent decades, far from what is believed, provides an added value and an opportunity to interact with a greater diversity of opinions and visions of our environment" (Sampé-Compté, Arandia and Elboj, 2012, p. 123).

"A true intercultural education values diversity and protects the cultural identity of minorities, placing them on an equal footing. If these conditions are respected, the immigrant pupil is provided with an appropriate framework for reconstructing his cultural identity, integrating new elements of the host culture into his previous cultural constructs" (Goenechea, 2014, p. 1066).

"The diversity of origins in the classrooms generates a new social situation that requires a pedagogical response, which is found in intercultural education" (González-Rodríguez, 2014, p. 230).

"We face a challenge, to promote a mediating role of education between origin and social destiny and to constitute a tool for the recognition that all individuals are citizens" (Martínez-Usarralde, Lloret-Catalá and Céspedes-Rico, 2016, p. $50)$.

The exercise consists of capturing on paper, in a visual and concise way, the progress that the teacher is experiencing while carrying out the course. The sketch should consist of three parts: what it was like before you started, what it is like during the course and what the teacher would like it to be after the end of it. The objective is to visualize with a future perspective how the teacher's attitude as a person and as an educator will change as far as cultural diversity is concerned, and to reflect on how cultural diversity 
works within the class and the school.

\section{Product 4}

The teachers will provide a drawing / concept map / outline / diagram / table or other kind of illustration showing three phases: before, during and after the participation in the project.

\section{Data collection and analysis}

Once the first version was completed, both the analysis instrument and the categories to be studied were validated by four education experts who made recommendations and suggestions for the final version of the instrument. The reliability of the instrument was finally approved unanimously: the agreement between reviewers was satisfactory.

The data generated by the teachers were classified using a constant comparison method of "content analysis" based on the work of Denzin and Lincoln (1994) and inspired by the methodology of the work of Guo, Arthur and Lund (2009). The product data were initially reviewed by the four members of the research team who began to build a taxonomy of emerging themes and sub-themes. In the second review of the data, the emerging themes and sub-themes were pooled, and this information was synthesized through interpretive phenomenological analysis (Smith, Jarman, and Osborn 1999). This group review fostered a holistic understanding of teacher statements. In the third phase, key phrases from teacher statements were identified through van Manen's (1990) selective reading approach.

As far as the first product is concerned, the xenophobic patterns emerging from the teachers' analysis have been studied and a division by countries has been carried out: it turned to be particularly relevant in order to show the subjective situation of each of the European states participating in the project. From the second product, three parallels have been established according to the response of the students to the micro-story, plus some exceptions that show other paths in the identification of prejudices and stereotypes. Finally, to analyse the third product, a categorization of the teachers' emotions and feelings is carried out, with a multimodal approach (Kress and van Leeuwen, 2006).

\section{Results and discussion}

\section{Product 1: Identification of general prejudices and stereotypes}

It is particularly interesting to underline the differences between the patterns that emerge from the analysis of the press, political parties, textbooks and spontaneous conversations according to the participants' countries of origin.

1. In the case of Spain, it is remarkable that most participants mention the Vox political party in their analysis. This far-right party has gained strength in the last elections (General Elections, November 2019), obtaining the $15.09 \%$ of votes at a national level, and therefore, the position of third political force in the national scene. The teachers are concerned about the continuous threats from this party to vulnerable groups such as the UFM (Martín, 2019). With respect to politics, they also refer to certain prejudices and 
stereotypes linked to Catalonia, and its perspective of superiority with respect to the rest of Spain. In this case, one professor even comments how historical terms such as "the Catalan-Aragonese crown" would be invented in order to instil a nationalist spirit based on a falsified past (he was referring to some textbooks). On the other hand, in the field of spontaneous conversations, the most recurrent issue is that of offensive language against the Gypsy ethnic group. Expressions such as "you are a gypsy", to say "thief", or "what a gypsy stuff" to express a denigrating act, perpetuate stereotypes against this collective. These issues have been studied since the 1980s, with little impact on the current reality of the school (Calero, 2002; Aguado, 2009; Gómez-Berrocal, 2009).

2. In the case of Greece, nationalist political parties are also mentioned. However, considering the special geographical situation of Greece and its particular circumstance of refugees' receptor, most of the collected phrases have to do with the feeling of "overflow" or "concern" of the country for the massive arrival of foreign migrants. The documents mention phrases such as " It is not that I don't like them, simply they are too many..." (by an Greek citizen, in English in the original document), "Greek society is getting older while refugees and immigrants are giving birth to many children" (from a newspaper), or "Many mountain villages are now inhabited only by immigrants" (from a newspaper). Reference is also made to the Albanian border issue, which has given rise to many prejudices and stereotypes about this neighbouring country.

3. In the case of Italy, the situation could appear to be a mixture of what has been detected in the two previous countries. On the one hand, the fact that it is one of the most important receiving ports of the so-called Mediterranean route makes the widespread perception of immigration as a kind of invasion (when it is clear from the statistics that the number of foreigners present in Italy constitutes a relatively small percentage of the current Italian population: cf. ISMU 20/02/2020). On the other hand, the weight of xenophobic political parties such as the Lega Nord and the responsibility of the media are recognized by several teachers. Thus, for example, one teacher comments that "Decrees and daily news on the landing of immigrants on Italian territory, consolidate a constant thought on the 'threat' of certain arrivals, for which the solution of prominent politicians would be "the sinking of the ship" (source $n^{o} 8$ ). Another teacher recalls that "Over the last few years in the public populist speeches of strong social and mould impact blatantly racist. The vocabulary used by politicians on social media and through news and print media is deliberately aggressive, disparaging, offensive. Such lexical drift heavily influences the emotions and the collective fears" (source $\mathrm{n}^{\mathrm{o}} 15$ ). This reverts directly to the widespread discourse of the population that alternates unjustified and prejudiced anger ("Waiting at the bus stop, you can easily grasp the complaint of someone who can't stand buses "full of blacks who don't pay for the ticket", it's not legitimate to know if whites have it or how such a statement can be proven", source $n^{\circ} 37$ ) to an empty pietism that in truth constitutes a direct attack on different customs ("[when] I am with other parents I keep on listening to the same kind of small talk focused on the "poor" Arab/Moroccan/Tunisian women who must suffer the heat because of their dresses and headscarves. It starts with some regret - people are sorry for them- but in the end the answer is always the same: "it is their fault, since they want to wear that kind of clothes and not ours" - source $\left.n^{\circ} 4\right)$.

However, a common theme in the reflections of all teachers is that racism is clearly not natural, but acquired from the stories that society offers, biased and motivated by individual interests. In relation to this, one impressive aspect is that all teachers explain 
the continuous media action to link the immigrant community to crime. In fact, two examples mentioned by the teachers can be compared and constitute a kind of parallel between two countries: Greece and Spain. One of the Greek teachers says literally: "Racism is to call students refugees not by their name but by the word 'refugee'" (source $\mathrm{n}^{\mathrm{o}} 21$ ). In relation to this, in Spain the far-right political party has attacked the UFM collective without mentioning at any time that they are talking about unaccompanied minors, using terminology based on acronyms so that most people won't feel any "empathy" or "compassion" with a vulnerable group such as children (Rubio Hancock, 2019): the language petrifies the collective into a homogeneous entity to avoid commiseration.

\section{Product 2: Identification of students' prejudices and stereotypes}

One of the most interesting aspects of this activity is the discussion that is generated around the controversial debate established since the arrival of the positivist current in the 19th and early 20th centuries in Latin America, with the famous text by Domingo Faustino Sarmiento Facundo or Civilization or Barbarism in the Argentine Pampas (1845). This antinomy has been put in crisis throughout the twentieth century by different authors who have tried to justify their position, understanding that each book is "a child of its time" (Arteta, 2016), but most critics recognized that everything started from a "cultural difference" that rather responded to a "colonial difference" (Lepe-Carrión, 2012). It is also true that, further from the 18th century analysis by Sarmiento, today's relationships among migrant and resident population should be analysed according to a decolonial and postcolonial perspective: starting from the studies on African and Asian decolonization by Said (1978), these investigations were applied on Hispanic American context by Todorov (1979) and Mignolo (2005) among others, and can offer both teachers and students the possibility to create a new pedagogy that recognises otherness as a force and not as a weakness. As authors like Paulo Freire, Enrique Dussel or Augusto Boal underlined during the 80s, studying (in) today's world should imply a modification of the spaces of enunciation, production and legitimisation of configuration when talking about Otherness. What Mignolo calls "border thinking" (2012) should be taken into account in everyday school routine, in order to break with the "modern Western and Eurocentric pedagogical discourse, problematizing the processes of hegemonic validity with which they have been constituted and historically operated" (Peñuelas, 2010, p. 181). This fact would collaborate with a new way of thinking that constructs the school as a space of identity under construction that confronts the student body with its "socially and academically constructed other" (Thielsch, 2019, p. 14).

Far from this, the results of this product show a quite different situation, on which it is absolutely necessary to work. The historical relationship in Latin America that derived from the time of the conquest, and from the supposed supremacy of the old continent over the new, is still a mirror of today's reality in which the "invaders" or "barbarians" are supposed to be the foreigners who come to occupy a territory belonging to the original inhabitants. In this case, xenophobia has Eurocentric overtones, since the majority of the population of the countries in which the study was carried out does not recognize as foreigners the migrants present on national territory if they were born in other European countries: only migrants with markedly non-Caucasian physical features are subject to discrimination, and with "clear classist overtone" (Alonso-Fernández, 2006, p. 177). These aspects can be clearly identified in the descriptions of the teachers' 
accounts, among which we find the following coincidences:

1. Students wrote alternative endings in which Fray Bartolomé either saves himself using his cunning, provoking the fear of the Indians by "making" the eclipse take place; or he escapes by deceiving the Indians with his intelligence. Almost none of the students saw the possibility that the "Indians" would succeed in their task.

2. The piece of literature is seen as something alien, or far removed from its reality. However, they interpret the text following stereotypes, just as they do with their own reality.

3. Most of the students are surprised at the end and disappointed because the "hero" is killed. There is an almost total identification with the conquering character.

The teaching/learning situation turns controversial when teachers try to explain why there is a prejudice in the text by Fray Bartolomé that is annulled in the ending chosen by the author. The fact that the friar is killed in the end provokes a total rejection of the figure of the Indians. However, some teachers open the perspective to their students so that they can understand the paradox, the irony cast by Monterroso.

A very particular case is led by a Greek teacher who questions the following:

Immediately afterwards, I read them the ending by Monterroso. It was a real surprise. No one thought that Indians could have the same knowledge, as they were barbarians in students' minds. So we arrived to discuss the power of stereotypes and how knowledge can come from different ways. But in the ending by Monterroso, the Indians kill Bartholome, so they are barbarians, the students insisted. That was a very critical question. Right, I replied, whoever kills is barbarian. Do we, as civilized, kill the other in a different way, when we leave to drown in the Mediterranean refugees and immigrants? So it is not the level of knowledge that makes the difference between civilization and barbarism. To be civilized means that we respect and protect the life of the other and we have no fear to accept and to coexist with different people, with different cultures and different habits (source $n^{\circ}$ 63).

The crucial question now is: if we let people die at sea, if we make no effort to welcome and integrate people fleeing from war, from hunger, aren't we perpetrating the same sacrifice as the Indians?

For another teacher, actually, the distance from the piece of literature (the time of the conquest) is particularly beneficial for the students to achieve empathy: "The fact that it refers to a place and time seemingly distant from contemporary Greek context gave the students the opportunity to develop their views much more freely than if it were a matter of hot reality" (source $\left.n^{0} 74\right)$.

On the other hand, one teacher has a particularly significant experience of prejudices universalization towards what is different. There are only foreigners in her class, mostly from Africa, Asia and Latin America. Most of them write a similar ending to the rest of the students in this analysis: Fray Bartolomé is freed thanks to his intelligence and power. However, when the end is known, the reaction is different:

Finally I give them photocopies of the Monterroso's end of the story. We read it together. All the students are very happy and surprised. We start a discussion about stereotypes. Many students from Africa and Asia mention that the culture and the way of living in their countries is unknown in Europe and North America. 
Many European and American people believe that people from Asia or Africa have no culture, education or history (source $\left.n^{\circ} 68\right)$.

Prejudices were strong in them too, but they are "happy" to know that the ending was different, that the story was unorthodox, and they immediately recognize the ignorant stereotypes that they must face in their daily reality.

\section{Product 3: Identification of teacher's own prejudices and stereotypes}

Most of the teachers involved in the project have participated in the latter task in a very creative way, making particularly interesting graphic representations through digital collages, photographic montages or more traditional drawings. Some of them have preferred a more discursive configuration, such as concept maps, and one has preferred to verbalize in a text his personal experience. In all cases, and independently of the teacher's country of origin, the general view of the experience has been extremely positive, highlighting the importance of cross-cultural training in values such as tolerance and acceptance of others in classroom dynamics for both students and teachers.

Many of them have recognized their scarce experience on the subject before they had taken part in the QuamMELOT project: thus, most of the words highlighted in the first phase, "before", are terms from the semantic field of ignorance, fear, concern about new situations: "worry [sic] about whether I will be able to overcome the language barrier; worry [sic] about whether I will be able to integrate the equally into the classroom"; "worried"; "confused"; "anxiety". Two teachers also emphasize how, before the experience, their teaching was more connected to academia and norms, and a third captures this sense of pointless effort in an emblematic image: a man tries to see what is behind a wall, climbing many stairs piled up on the floor.

Only one teacher underlines the enthusiasm that preceded this new challenge: the image of a female figure dancing through the flames is accompanied by the words "Full of energy, almost on fire, to change things and make things right" (source $n^{\circ} 94$ ).

The intermediate phase, "during", is characterized by the effort of searching: "effort", "searching", "change", "challenge" are some of the most frequent words, sometimes accompanied by doubt. The conflict between the methodologies used before and after the QuamMELOT training is shown by a teacher in the image of two arrows pointing to opposite directions, indicating respectively "old way" and "new way". In any case, as a teacher notes, "it is not easy but so worth it!" (source $n^{\circ} 98$ ).

The next phase, "after", is indicated as a moment of satisfaction, great evolution and at the same time enthusiasm to continue with the work: "A fulfilling sense of serenity. I feel able to protect my students. They learn how to walk on their own all together, included and integrated" (source $\mathrm{n}^{\mathrm{o}} 110$ ), one teacher notes.

\section{Conclusions}

The pedagogical approach of the QUAmMELOT project allows us to highlight the importance of the interinstitutional collaboration between the research field and the real context of school education (Trueba \& Bartolomé, 2000; Lamas \& Lazuela, 2012). 
One of the most relevant issues in the analysis of the pedagogical proposal is that the Other must necessarily be considered from a post-colonial perspective:

Currently, intercultural education is proposed as a theoretical-practical educational action proposal where the recognition of the existence of the "Others" as subjects possessing a different culture and the knowledge of what this means in terms of similarities and differences with the school culture itself-characterized by multiple influences- prevails, promoting an exchange of values for the emergence of a more democratic and supportive situation (Leiva, 2010, p. 68).

Unfortunately, the multiplication of xenophobic instances is increasingly common in several European countries, as the global phenomenon of migration impacts on our daily lives and there are many populist voices willing to take advantage of a climate of fear for their own interests. It is a precise duty of teachers of all kinds and degrees to be aware of this danger that undermines the root of the principles of acceptance and multiculturalism on which Europe is founded, since "efforts must be invested in implementing language learning programmes, additional support aids during schooling, and setting up schools and procedures that avoid ghettos as well as segregation" (Essomba, 2012, p. 137). Following this research, it is suggested that a pedagogical reform emerges in school programs where the voices of immigrants are really heard (Trueba and Bartolomé, 2000) and where there is specific teacher training that allows processes of deep self-reflection on their sense of diversity (Guo, Arthur and Lund, 2009) leading to more positive environments in the multicultural classroom (Cherng \& Davis, 2019). Above all, this process is required to meet the following objectives promulgated by Frujas and Roxas (2016):

(a) advancing the role of genuine cross-cultural relationships over traditional forms of cross-cultural competence in multicultural educational spaces and $(b)$ abdicating the search for cultural authenticity implied in some multicultural education practice in favour of facilitating cultural agency for newcomer youth (p. 155).

In this way, teachers will be able to train students and turn them into active subjects of the reality that surrounds them, making them aware of how, through their empathy, they themselves can plant the foundations of a future of peace that begins today.

\section{Acknowledgement}

This paper has been conceived within the European QuamMELOT Project ("Qualification for Minor Migrants Education and Learning Open Access - On Line Teacher-Training”, Erasmus+, KA2 School Sector, Strategic Partnerships, Reference 2017-1-IT02-KA201-036610), which has been developed between 12/31/2017 and 08/31/2020 under the coordination of Dr. Raffaella Biagioli from the University of Florence in Italy. This project involves academic and non-academic entities from Greece, Italy, Denmark and Spain. The University of Seville is the Spanish partner of the Project. The person in charge in Spain is Professor José González-Monteagudo. The research team at the University of Seville is composed by Olga Moreno-Fernández, Elena Guichot-Muñoz, José Antonio Pineda-Alfonso, Mario Ferreras-Listán, María Puig-Gutiérrez, María A. Tenorio-Rodríguez, Verónica Sevillano-Monje, Mario LeónSánchez and Miriam Zamora-Serrato. Dr. David Herrera-Pastor (University of Málaga) is also part of the project team. The information and views presented in this publication are those of the authors and do not reflect the official opinion of the European Union. 
Neither the institutions and bodies of the European Union nor any person acting on their behalf may be held responsible for the use which might be made of the information contained therein.

\section{References}

Aguado Odina, T. (2009). The Education of ethnic, racial and cultural minority groups in Spain. In J. A. Banks, (Ed.). (2009). The Routledge international companion to multicultural education (pp. 474-485.). Routledge.

Allemann-Ghionda, C. (2009). From intercultural education to the inclusion of diversity: Theories and policies in Europe. In J. A. Banks, (Ed.). (2009). The Routledge international companion to multicultural education (pp. 134-145). Routledge.

Alonso-Fernández, F. (2006). El hombre libre y sus sombras: una antropología de la libertad: los emancipados y los cautivos [The free man and his shadows: an anthropology of freedom: the emancipated and the captives]. Barcelona: Anthropos Editorial.

Arteta Ripoll, C. (2016). Barbarie y civilización en el pensamiento jusfilosófico latinoamericano [Barbarism and civilization in Latin American jusphilosophical thought]. Advocatus, 13(26), 239-252. DOI: $\quad 10.18041 / 0124-$ 0102/advocatus.26.945

Calero Fernández, M. Á., Forgas Berdet, E., \& Lledó, E. (2002). La presencia del racismo en el discurso lexicográfico: su repercusión en la enseñanza [The presence of racism in lexicographic discourse: its impact on education]. Textos: didáctica de la lengua y de la literatura, 31, 65-74.

Castro-Gómez, S., \& Grosfoguel, R. (Eds.). (2007) El giro decolonial. Reflexiones para una diversidad epistémica más allá del capitalismo global [The de-colonial turn. Reflections for an epistemic diversity beyond global capitalism]. Bogotá: Siglo del Hombre.

Cherng, H. Y. S., \& Davis, L. A. (2019). Multicultural matters: An investigation of key assumptions of multicultural education reform in teacher education. Journal of Teacher Education, 70(3), 219-236.

Contreras, D. M. P. (2010). ¿América Latina Des-Colonizada? Cuerpo y espacialidad en el proyecto modernidad/colonialidad [De-Colonized Latin America? Body and spatiality in the modernity/coloniality Project]. Revista Colombiana de Educación, 59, 149-166.

Denzin, N.K. and Lincoln, Y.S., eds. (1994). Handbook of qualitative research. Thousand Oaks, CA: Sage.

Dussel, E. (2003). Europa, modernidad y eurocentrismo [Europe, modernity and Eurocentrism]. In E. Lander (Comp.), La colonialidad del saber: eurocentrismo $y$ ciencias sociales. Perspectivas latinoamericanas [The coloniality of knowledge: Eurocentrism and social sciences. Latin American perspectives] (pp. 41-53). Buenos Aires: CLACSO.

Essomba, M.A. (2012) Inmigración, sociedad y educación en la UE. Hacia una política educativa de plena inclusión [Immigration, society and education in the EU Towards a fully inclusive education policy]. Cultura y Educación, 24(2), 137148, https://doi.org/10.1174/113564012804932074

Fruja Amthor, R., \& Roxas, K. (2016). Multicultural education and newcomer youth: Re-imagining a more inclusive vision for immigrant and refugee students. Educational studies, 52(2), 155-176. 
Fundación ISMU (2020). Residenti stranieri in aumento - Comunicato stampa 11 febbraio 2020 [Foreign residents on the rise - Press release February 11, 2020]. https://www.ismu.org/comunicato-stampa-residenti-stranieri-in-aumento/

Glick, J., \& Hohmann-Marriott, B. (2007). Academic performance of young children in immigrant families. The significance of race, ethnicity, and national origins. International Migration Review, 41, 371-402.

Goenechea, C. (2014). Análisis de la presencia de la cultura de origen de los menores inmigrantes en el sistema educativo andaluz [Analysis of the presence of the culture of origin of immigrant minors in the Andalusian education system]. En Actas del Congreso Internacional Infancia en Contextos de Riesgo. 20-22 de noviembre de 2014, Huelva.

Gómez-Berrocal, C. (2009). Lenguaje, procesos psicosociales y prejuicio contra los gitanos en España [Language, psychosocial processes and anti-Roma prejudice in Spain]. Anales de Historia Contemporánea, 25, 133-147.

González-Rodríguez, J. A. (2014). La Mediación intercultural como práctica pedagógica en la educación secundaria. Aprender a ser docente en un mundo en cambio [Intercultural mediation as a pedagogical practice in secondary education. Learning to be a teacher in a changing world]. Simposio internacional (pp. 228-234). Barcelona Universidad de Barcelona.

Hajisoteriou, C., \& Angelides, P. (2017). Collaborative art-making for reducing marginalisation and promoting intercultural education and inclusion. International Journal of Inclusive Education, 21(4), 361-375.

Holm, G., \& Londen, M. (2010). The discourse on multicultural education in Finland: Education for whom?. Intercultural Education, 21(2), 107-120.

Kress, G. R., \& Van Leeuwen, T. (2006). Reading images: The grammar of visual design. Londres: Routledge.

Krulatz, A., \& Iversen, J. (2020). Building inclusive language classroom spaces through multilingual writing practices for newly-arrived students in Norway. Scandinavian Journal of Educational Research, 64(3), 372-388.

Lamas, M., \& Lalueza, J.L. (2012) Apropiación de un modelo colaborativo en escuelas multiculturales con alumnado en situación de exclusión social [Appropriation of a collaborative model in multicultural schools with socially excluded students]. $\begin{array}{llll}\text { Cultura } & y & \text { Educación, } & \text { 24(2), }\end{array}$ https://doi.org/10.1174/113564012804932083

Leiva, J. (2010). Práctica de la interculturalidad desde la perspectiva docente: análisis y propuestas pedagógicas [Practice of interculturality from the teaching perspective: analysis and pedagogical proposals]. Cultura y Educación, 22(1), 67-84. https://doi.org/10.1174/113564010790935240

León, B., Felipe, M.E., \& Gómez, T. M. (2010). Variables individuales que influyen en las actitudes hacia la inmigración en el ámbito escolar [Individual variables that influence attitudes towards immigration in the school environment]. Anales de psicología, 26 (2), 359-368.

Lepe-Carrión, P. (2012). Civilización y barbarie: La instauración de la "diferencia colonial" durante los debates del siglo XVI y su encubrimiento como "diferencia cultural" [Civilization and Barbarism: The Establishment of "Colonial Difference" during the 16th Century Debates and its Cover-up as "Cultural Difference"]. Andamios, 9(20), 63-88.

López-Noguero, F. (2002). El análisis de contenido [Content analysis]. En F. LópezNoguero \& T. Pozo-Llorente (Coord.), Investigar en educación social [Research 
in social education] (pp. 129-138). Sevilla, España: Consejería de Relaciones Institucionales.

Martín, M. (2019). El Defensor del Pueblo alerta sobre la xenofobia contra los menores inmigrantes desatada en campaña [Ombudsman warns of xenophobia against immigrant children in campaign]. El Pais. https://elpais.com/politica/2019/11/08/actualidad/1573211898_998451.html

Martínez-Usarralde, M. J., Lloret-Catalá, C., \& Céspedes-Rico, M. (2017). Lo que hacen mejores las escuelas integradoras de alumnado inmigrante [What immigrant friendly schools do best]. Pedagogía Social Revista Interuniversitaria, 29, 41-54. DOI: 10. SE7179/PSRI_2017.29.03

Mignolo, W. (2005). Cambiando las éticas y las políticas del conocimiento: lógica de la colonialidad y postcolonialidad imperial [Changing the ethics and politics of knowledge: the logic of coloniality and imperial post-coloniality]. Tabula rasa, $3,47-72$.

Mignolo, W. (2012). Local histories/global designs: Coloniality, subaltern knowledges, and border thinking. Princeton University Press.

Ministerio de Educación (2020). Datos y cifras Curso escolar 2019/2020 [Facts and figures School year 2019/2020]. Madrid, España: Ministerio de Educación. https://www.educacionyfp.gob.es/dam/jcr:b998eea2-76c0-4466-946e965698e9498d/datosycifras1920esp.pdf

Ministerio de Interior (2019). Inmigración irregular 2019. [Irregular immigration 2019. Cumulative data from 1 January to 31 December]. Madrid, España: Ministerio de Interior. http://www.interior.gob.es/documents/10180/11113854/informe_quincenal_acu mulado_01-01_al_01-12-2019.pdf/07447a3f-a2a2-404d-a4a1-4e32d961fba2

Morales, L. (2006). La integración lingüistica del alumnado inmigrante: propuestas para el aprendizaje cooperativo [The linguistic integration of immigrant students: proposals for cooperative learning]. Madrid: Catarata.

Navas, L., Holgado, F. P., \& Sánchez, A. (2009). Predicción de los estereotipos académicos ante los estudiantes inmigrantes [Predicting academic stereotypes to immigrant students]. Horizontes Educacionales, 14(2), 37-47.

Oltra, M. A. (2015). Educación intercultural, diversidad y creatividad en el aula a través del teatro: los títeres [Intercultural education, diversity and creativity in the classroom through theatre: the puppets]. Didáctica. Lengua y la Literatura, 27 (1), 167-182.

Parejo-Llano, J.L., Ruiz-Requies, I., \& González-Pedraza, A. (2020). Refugees: a new intercultural education for global citizenship. Revista Electrónica Interuniversitaria de Formación del Profesorado, 23(1), 113-124.

Piñuel, J. (2002). Epistemología, metodología y técnicas del análisis de contenido [Epistemology, methodology and techniques of content analysis]. Estudios de Sociolingüística, 3(1), 1-42.

Porter, A., \& MacLeod, D. (1996). Educational progress of children of immigrants: The roles of class, ethnicity and school context. Sociology of Education, 69, 255-275.

Rubio Hancock, J. (2019). Cómo el término "mena" invisibiliza a los niños migrantes [How the term "UFM" makes migrant children invisible]. El Pais, 13/11/2019. https://verne.elpais.com/verne/2019/11/12/articulo/1573549678_9005 03.html

Said, E. (1978). Orientalism. London: Routledge.

Samovar, L. A., Porter, R. E., McDaniel, E. R., \& Roy, C. S. (2014). Intercultural communication: A reader. Cengage Learning. 
Sampé-Compte, M., Arandia, M., \& Elboj, C. (2012). Actuaciones educativas que están consiguiendo éxito educativo en centros educativos con alumnado inmigrante [Educational actions that are achieving educational success in schools with immigrant students]. Revista Interuniversitaria de Formación del Profesorado, 73(26,1), 119-132.

Sarmiento, D.F. (1845). Facundo: civilización y barbarie [Facundo: civilization and barbarism]. Buenos Aires: Editorial Claridad.

Smith, J., Jarman, M. and Osborn, M. 1999. "Doing interpretative phenomenological analysis". In Murray, M. and Chamberlain, K. (eds.) Qualitative health psychology (pp. 218-40). London: Sage.

Strandberg, M., \& Lindberg, V. (2012). Feedback in a multiethnic classroom discussion: a case study. Intercultural Education, 23(2), 75-88.

Thielsch, A. (2019). Listening out and dealing with otherness. A postcolonial approach to higher education teaching. Arts and Humanities in Higher Education, O(0), 117. Doi: $10.1177 / 1474022219832459$

Van Dijk, T.A. (2001). Discourse and Racism. In D. Goldberg \& J. Solomos (Eds.), The Blackwell Companion to Racial and Ethnic Studies. Reino Unido: Oxford.

Van Manen, M. (1990). Researching lived experience: Human science for an action sensitive pedagogy. London: Althouse Press.

Wane, N. N., \& Todd, K. L. (Eds.). Decolonial pedagogy: Examining sites of resistance, resurgence, and renewal. London: Palgrave.

Walsh, C. E. (2014). Pedagogías decoloniales caminando y preguntando: notas a Paulo Freire desde Abya Yala [Decolonial pedagogies walking and asking: notes to Paulo Freire from Abya Yala]. Entramados: educación y sociedad, 1, 17-30. 